\title{
The Strategies of Psychological Richness of Personality
}

\section{Стратегї̈ ресурсної насиченості особистості}

\author{
Olena Shtepa \\ Ph.D. in Psychology, Assistant Professor, Ivan Franko Natio- \\ nal University of Lviv, Lviv (Ukraine) \\ ORCID ID: https://orcid.org/0000-0002-5396-3279 \\ Researcher ID: S-9557-2018 \\ E-mail: Olena.Shtepa@lnu.edu.ua
}

\section{Олена Штепа}

Кандидат психологічних наук, доцент, Львівський національний університет імені Івана Франка, м. Львів (Україна)

\section{ABSTRACT}

The aim of the article is empirical identification of the strategies of psychological richness of personality.

Methods of the study. The psychological survey is applied including the following techniques: personal resourcefulness questionnaire, psychological resourcefulness questionnaire, diagnostic questionnaire of existential resources indicators, virtue and strength of character questionnaire, crisis coping questionnaire, psychological well-being questionnaire, methods of assessment and prediction of psychological development of situations of interpersonal interaction. The methods of mathematical and statistical analysis, like one-way ANOVA, cluster analysis, classification analysis have been used. The research was implemented using the Goldmark's model, which involved alternative hypotheses and determined the practical and theoretical significance of the

Address for correspondence, e-mail: kpnu_lab_ps@ukr.net Copyright: (C) Shtepa Olena

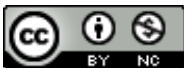

The article is licensed under CC BY-NC 4.0 International

(https://creativecommons.org/licenses/by-nc/4.0/)

(C) Shtepa Olena

DOI (article): https://doi.org/10.32626/2227-6246.2020-48.313-338 
results of the research. The methods of verification and interpretation have been implemented.

The results of the research. According to the results of verification the following strategies of psychological richness are singled out: personality perfectness, personality maturity, existential perfectness, existential motivation, basic beliefs. The hardiness is shown to be doubtfully defined as the strategy of the psychological richness of personality. According to the results of the classification analysis, it is determined that the strategy of personality perfectness implies the possibilities of life self-fulfillment of personality (the predictor's rank is 100\%). The analysis of the correlation between strategies of personality's psychological richness in the structure of personal self-fulfillment proves the strategy of personality's perfectness is only 5\%, while the strategy of existential fulfillment is 55\%, and its predictor's rank is $23 \%$. The results of classification analysis using the k-averages method showed, that there were two types of opportunities for personal self-fulfillment that differed in terms of the strategy of existential fulfillment.

Conclusions. The strategies of psychological richness of personality are characterized as a reflexively predetermined distribution of psychological factors in the areas of intentional experience, encompassed by wisdom of a man. The empirical indicators of strategies of personality's psychological richness are the systemic reflection, wisdom, psychological resources of personality. Each of the defined strategies is interpreted to characterize certain functions in the person's reflective image of his / her own possible life self-fulfillment. The characteristics of the functions of psychological richness of personality are relevant for predicting and analyzing the effectiveness of productive functioning of personality.

Key words: strategies of psychological richness of personality, psychological resources, systemic reflection, possibilities of life self-fulfillment, wisdom, strategizing of psychological richness of personality.

\section{Вступ}

Аналіз ресурсної насиченості особистості, яку було схарактеризовано як «рефлексивно зумовлену здатність перетворення кількісного вмісту їі психологічних ресурсів» (Штепа, 2020: 233), показав важливість з'ясування характеру зазначених перемін. Зокрема, у дослідженнях Д. Леонтьєва узагальнено, що (не)достатність ресурсів зумовлює (C) Shtepa Olena

DOI (article): https://doi.org/10.32626/2227-6246.2020-48.313-338 
рівень психологічного благополуччя особистості (Леонтьев, 2016: 22). На погляд I. Титова (Титов, 2019: 156), на продуктивність мобілізації ресурсів впливає рефлексія, що, своєю чергою, зумовлена розв'язанням людиною певних життєвих труднощів (Савчин, 2016: 239). О. Рязанцевою також обгрунтовано, що саме у контексті ситуації психологічної кризи виявляються процеси втрати, мобілізації та накопичення певних ресурсів (Рязанцева, 2012: 55). На основі вказаного можна зробити висновок, що нестача психологічних ресурсів спричиняє труднощі якомога повнішої та щасливої самореалізації людини. Водночас характеристика особи в некласичній психології як суб'єкта інтерпретації (Пушкарев, 2012: 20) дала нам змогу стверджувати, що не життєві труднощі є наслідком дефіциту ресурсів, а недоцільне спрямування людиною власних ресурсів зумовлює їі особистісні кризи. У реалізованому нами дослідженні щодо компонентів ресурсної насиченості було доведено, що важливішою за кількість наявних у людини ресурсів є ї здатність ними оперувати, відтак, ресурсна насиченість може визначатися у певних стратегіях (Штепа, 2020: 247).

У філософському тлумаченні «стратегія - це мудрість, помножена на точно обраний вектор атаки з оцінкою ресурсної обмеженості» (Квинт, 2016: 16). У прикладному аспекті стратегію характеризують як план конкурентної гри, що вибудовується через формулювання місії, цінностей, мотивації, критеріїв досягнень (Collis \& Rukstad, 2008: 3). У некласичній психології як стратегії особистості характеризують «особистісні динамічні властивості, що значною мірою можуть бути усвідомлювані людиною, тобто обираються нею, і характеризують їі спрямованість» (Леонтьев, 2010). На основі характеристики особистісних ресурсів як гнучких властивостей особистості (state-like) (Иванова, 2018: 87), не протиставлення стану і процесу в некласичній філософії (Черникова, 2007: 44), можливостей (не)довільної активації ресурсів (Хазова, 2014: 50), а також визначення ресурсів у

(c) Shtepa Olena

DOI (article): https://doi.org/10.32626/2227-6246.2020-48.313-338 
співвідношенні з життєвими задачами (Леонтьев, 2014: 98) і внутрішньою суб'єктивною реальністю (Низовских, 2014: 367), ми припустили, що стратегіями ресурсної насиченості можуть бути певною мірою рефлексовані людиною динамічні особистісні властивості, які характеризують їі внутрішній світ і ставлення до себе й інших людей.

Психологічну реальність особистості в сучасній некласичній психології характеризують через феномен «Я» людини і пов'язану з ним мотиваційну спрямованість (Капустин, 2017: 70). Жћиттєві задачі у сучасній психології означено як «спосіб реалізації найважливіших форм самопрогнозування», що «задають масштаб і продуктивність самоздійснення» (Як будувати власне життя..., 2012: 55). Отже, стратегування особистості слід відрізняти від екзистенціювання. Останне, згідно з М. Савчиним (Савчин, 2016: 199), чиниться стосовно цінностей особистості. Стратегування ресурсної насиченості особистості, на наш погляд, відбувається відносно іï інтенційності - «структури, у якій осмислюється людиною їі минулий досвід і конструюється майбутній» (Мау, 1969).

На основі здійсненого теоретичного аналізу ми охарактеризували стратегування ресурсної насиченості особистості як рефлексивно зумовлений розподіл психологічних ресурсів за напрямами інтенційного досвіду, що охоплюється мудрістю людини. Для психологічної практики актуалізування ресурсів особистості важливою є емпірична верифікація розподілу і спрямування ресурсної насиченості, проте на тепер така перевірка не здійснювалася через недостатність емпіричних методик діагностики психологічних ресурсів. Вважаємо, що визначення напрямів стратегування ресурсної насиченості може надати підстав для характеристики ефективності функціонування особистості.

Мета дослідження - емпірично визначити напрями стратегування ресурсної насиченості особистості. 


\section{Завдання статті}

1. Представити емпіричні показники стратегування ресурсної насиченості.

2. Представити емпіричне обгрунтування спрямування компонент ресурсної насиченості за певними її стратегіями.

3. Проінтерпретувати відповідність емпіричних результатів верифікації напрямів стратегій ресурсної насиченості до показників стратегування.

\section{Методи та методики дослідження}

Уміст ресурсної насиченості було емпірично визначено за показниками, обгрунтованими у дослідженні О. Штепи (Штепа, 2020: 234), а саме: ресурси психологічного виживання, психологічне благополуччя, сили характеру, персональна ресурсність, екзистенційні ресурси, когерентність, толерантність до невизначеності, психологічна ресурсність. Також ми долучили до визначених показників ресурси взаємин, які можна проінтерпретувати як такі на основі даних психодіагностичної методики оцінки та прогнозування психологічного розвитку ситуацій міжособистісної взаємодії О. Бандаренко. Для визначення системної рефлексії застосовано опитувальник рефлексії Д. Леонтьева, Є. Осіна. Для визначення мудрості виокремлено дані за шкалою «Мудрість» опитувальника «Сили характеру» (методика Values in Action K. Петерсона і M. Селігмана; в адаптації I. Буровіхіної, Д. Леонтьєва, Є. Осіна).

Емпіричними дескрипторами стратегій ресурсної насиченості особистості було допущено такі, що, на наш погляд, характеризують самоздійснення і визначають спрямованість особистості, а саме: екзистенційну здійсненність, особистісну здійсненність, екзистенційну мотивацію, базові переконання, життєстійкість, особистісну зрілість.

Зазначені стратегії було діагностовано за допомогою відповідних методик, зокрема шкали екзистенції (Existenzskala) А. Ленгле та К. Орглера (в адаптації С. Крівцової), опиту-

(C) Shtepa Olena

DOI (article): https://doi.org/10.32626/2227-6246.2020-48.313-338 
вальника особистісної здійсненності О. Штепи, опитувальника екзистенційної здійсненності (екзистенційних мотивацій) В. Шумського, Є. Уколової, Є. Осіна, Я. Лупандіна, шкали базових переконань Р. Янова-Бульмана, тесту життєстійкості (опитувальник Hardiness Survey C. Мадді; в адаптації Д. Леонтьева і Є. Рассказової), опитувальника особистісної зрілості О. Штепи.

Емпіричними критеріями інтерпретування певної особистісної динамічної властивості як стратегії ресурсної насиченості нами визначено такі: 1) дискримінантна модель ресурсної насиченості містить певну динамічну властивість; 2) дискримінантна модель мудрості містить певну динамічну властивість; 3) певна компонента ресурсної насиченості вміщується дискримінантою моделлю системної рефлексії; 4) певна динамічна властивість вміщується дискримінантною моделлю системної рефлексії; 5) певні компоненти ресурсної насиченості зумовлюють зміни окресленої динамічної властивості; 6) певні компоненти ресурсної насиченості є предикторами окресленої динамічної властивості. Вважаємо прийнятним на основі характеристики феномену «Я» людини (Капустин, 2017: 70) й означення інтенційності (Мау, 1969) припустити, що нерозподілена за певними напрямами сукупність психологічних ресурсів є ложливістю життєвого самоздійснення особистості.

У дослідженні взяли участь 367 осіб (із них 59\% жінок, $41 \%$ чоловіків) віком від 22 до 52 років $(\mathrm{M}=38,1)$ (студенти-магістранти, які навчаються на денній і заочній формах навчання за напрямами психології й освітньої педагогіки, слухачі Інституту доуніверситетської та післядипломної освіти за напрямами права і філології, менеджери середньої ланки, офісні працівники). Дослідження реалізовано за моделлю Голдмарка, що передбачає висунення альтернативних гіпотез і визначення практичної й теоретичної значущості результатів дослідження. 


\section{Результати та дискусії}

Із метою встановити допустимість емпіричної моделі ресурсної насиченості, доповненої компонентою ресурсів взаємин, було здійснено дискримінантний аналіз, що показав коректність класифікування на 90,7\%. Дані дискримінантної моделі ресурсної насиченості, що містить усі верифіковані компоненти, розраховано за прийнятного значення Wilks' Lambda $(0,38)$. Із метою визначити, чи певні динамічні властивості можна допускати як стратегії ресурсної насиченості, було здійснено дискримінантний аналіз, що показав коректність класифікування на 65,5\% за високого значення Wilks' Lambda $(0,68)$ (табл. 1$)$.

Таблищя 1

Дискримінантна модель стратегій ресурсної насиченості

(на основі 6 компонент, показник Wilks' Lambda 0,68; показник класифікування - загальний рівень ресурсної насиченості)

\begin{tabular}{|c|c|c|c|c|c|c|}
\hline $\begin{array}{c}\text { Стратегії ресурсної } \\
\text { насиченості }\end{array}$ & 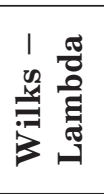 & 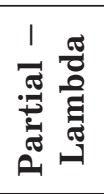 & 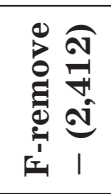 & $\frac{0}{0}$ & $\frac{\dot{e}}{\stackrel{0}{0}}$ & 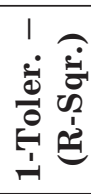 \\
\hline \begin{tabular}{|l} 
Екзистенційна \\
здійсненність
\end{tabular} & 0,79 & 0,85 & 34,25 & 0,00 & 0,59 & 0,40 \\
\hline \begin{tabular}{|l} 
Екзистенційна \\
мотивація
\end{tabular} & 0,72 & 0,94 & 11,08 & 0,00 & 0,74 & 0,25 \\
\hline $\begin{array}{l}\text { Особистісна } \\
\text { здійсненність }\end{array}$ & 0,71 & 0,96 & 7,79 & 0,00 & 0,64 & 0,35 \\
\hline Базові переконання & 0,69 & 0,98 & 4,04 & 0,01 & 0,88 & 0,11 \\
\hline ЖЖиттєстійкість & 0,69 & 0,97 & 4,36 & 0,01 & 0,76 & 0,23 \\
\hline Особистісна зрілість & 0,69 & 0,98 & 3,74 & 0,02 & 0,71 & 0,28 \\
\hline
\end{tabular}

За результатами дискримінантного аналізу було встановлено, що допустимо надалі аналізувати екзистенційну здійсненність, особистісну здійсненність, екзистенційну мо- 
DOI: https://doi.org/10.32626/2227-6246.2020-48 2020. ВиПУСК 48

тивацію, базові переконання, життєстійкість, особистісну зрілість як можливі стратегії саме ресурсної насиченості.

Із метою з'ясувати вираженість стратегій ресурсної насиченості відносно її компонент було здійснено багатофакторний аналіз, який кумулятивно пояснив $68 \%$ дисперсії та показав структурування аналізованих показників за шістьма факторами (табл. 2).

Таблиця 2

Результати багатофакторного аналізу показників компонент і стратегій ресурсної насиченості

\begin{tabular}{|c|c|c|c|c|c|c|}
\hline $\begin{array}{r}\text { Показну } \\
\text { і страт } \\
\text { на }\end{array}$ & 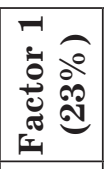 & 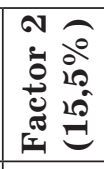 & 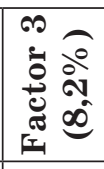 & 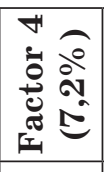 & 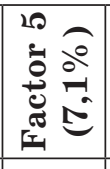 & 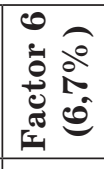 \\
\hline Іси &, 88 & 0,12 & $-0,02$ & 0,05 & $-0,05$ & 0,00 \\
\hline IcI & 66 &, 04 & 0,21 & 0,02 & 0,18 & 0,15 \\
\hline 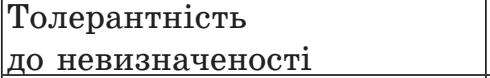 & 0,07 & 0,01 & $-0,10$ & 0,06 & 0,83 & 0,00 \\
\hline Ког &, 69 & $-0,01$ & $-0,09$ & 0,05 & 0,01 & $-0,28$ \\
\hline Eк & 0,46 & 0,03 & 0,18 & $-0,03$ & 0,44 & 0,08 \\
\hline иил & 0,47 & $-0,01$ & 0,51 & $-0,01$ & 0,26 & $-0,14$ \\
\hline $\begin{array}{l}\text { Ресур } \\
\text { вижи }\end{array}$ & 0,81 & 0,05 & $-0,13$ & 0,05 & 0,03 & 0,00 \\
\hline Перс &, 04 & 0,11 & 0,03 & $-0,00$ & $-0,02$ & $-0,93$ \\
\hline $\mathrm{Pec}$ &, 13 & $-0,02$ & $-0,88$ & 0,00 & 0,14 & $-0,01$ \\
\hline $\begin{array}{l}\text { Стра } \\
\text { здій }\end{array}$ & 0,24 & 0,70 & 0,01 & 0,36 & $-0,11$ & $-0,08$ \\
\hline $\begin{array}{l}\text { Стра } \\
\text { зрілі }\end{array}$ & 0,17 & 0,79 & 0,05 & 0,15 & $-0,01$ & $-0,04$ \\
\hline Стра &, 02 & 0,76 & $-0,05$ & $-0,13$ & $-0,02$ & 0,06 \\
\hline $\begin{array}{l}\text { Стратегія: екзистенційна } \\
\text { здійсненність }\end{array}$ & 0,19 & 0,24 & 0,09 & 0,71 & $-0,23$ & 0,13 \\
\hline $\begin{array}{l}\text { Стратегія: екзистенційна } \\
\text { мотивація }\end{array}$ & -( & 0,82 & 0,02 & 0,02 & 0,14 & $-0,12$ \\
\hline $\begin{array}{l}\text { Стратегія: базові } \\
\text { переконання }\end{array}$ & $-0,07$ & $-0,04$ & $-0,09$ & $\mathbf{0 , 7 4}$ & 0,29 & -0, \\
\hline
\end{tabular}

(C) Shtepa Olena 
Результати багатофакторного аналізу продемонстрували чітку вираженість компонент і можливих стратегій ресурсної насиченості та їх відокремленість, що дало нам змогу інтерпретувати стратегії як форми вираження ресурсного змісту особистості.

Для того, щоб з'ясувати, чи певні компоненти ресурсної насиченості є чинниками означеної динамічної властивості, було здійснено однофакторний дисперсійний аналіз. За його результатами (табл. 4, SS - Effect) було встановлено, що психологічна і персональна ресурсність, когерентність і ресурси психологічного виживання зумовлюють зміни особистісної здійсненності як можливості стратегії ресурсної насиченості; персональна ресурсність і ресурси психологічного виживання - особистісної зрілості; ресурси психологічного виживання - екзистенційної здійсненності; персональна ресурсність - екзистенційної мотивації; толерантність до невизначеності й ресурси психологічного виживання - базових переконань. Саме ресурси психологічного виживання зумовлюють зміни у чотирьох із шести можливих стратегій ресурсної насиченості. Для того, щоб з'ясувати, чи певні компоненти ресурсної насиченості є предикторами означеної динамічної властивості, було здійснено класифікаційний аналіз за методом Predictor Variable Rankings (табл. 3).

Слід підкреслити, що психологічне благополуччя є $100 \%$ предиктором як для екзистенційної здійсненності, так і для базових переконань.

Із метою встановити, чи дійсно певні ресурси розподіляються за вираженими стратегіями ресурсної насиченості, було застосовано дискримінантний аналіз, за результатами якого з'ясовано, що коректність класифікування за дискримінантними моделями передбачуваних стратегій певних компонент ресурсної насиченості є у межах $49-77 \%$ за значення Wilks' Lambda 0,91-0,97, що свідчить про високу достовірність даних. Дискримінантна модель системної рефлексії містила усі передбачувані стратегії з коректністю класифікування 92\% за значення Wilks' Lambda 0,78.

(c) Shtepa Olena

DOI (article): https://doi.org/10.32626/2227-6246.2020-48.313-338 
Результати класифікаційного аналізу компонент ресурсної насиченості як предикторів її стратегій (ранг предиктора*)

\begin{tabular}{|c|c|c|c|c|c|c|}
\hline \multirow[b]{2}{*}{$\begin{array}{c}\text { Компоненти ресурсної } \\
\text { насиченості }\end{array}$} & \multicolumn{6}{|c|}{ Стратегії ресурсної насиченості } \\
\hline & 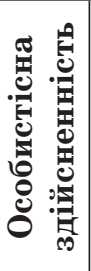 & 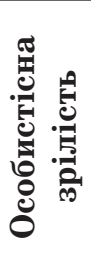 & 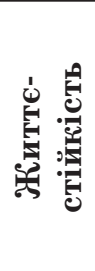 & $\begin{array}{l}\text { D. } \\
\end{array}$ & 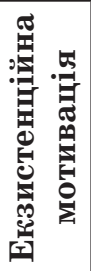 & 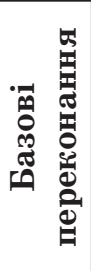 \\
\hline Психологічна ресурсність & 100 & 37 & 97 & 76 & 74 & 24 \\
\hline Психологічне благополуччя & 28 & 45 & 41 & 100 & 41 & 100 \\
\hline $\begin{array}{l}\text { Толерантність до } \\
\text { невизначеності }\end{array}$ & 58 & 48 & 65 & 73 & 65 & 68 \\
\hline Когерентність & 91 & 100 & 58 & 55 & 40 & 96 \\
\hline Екзистенційні ресурси & 48 & 83 & 100 & 55 & 47 & 96 \\
\hline Сили характеру & 33 & 72 & 77 & 93 & 64 & 61 \\
\hline $\begin{array}{l}\text { Ресурси психологічного } \\
\text { виживання }\end{array}$ & 81 & 65 & 62 & 66 & 100 & 66 \\
\hline Персональна ресурсність & 12 & 22 & 37 & 55 & 19 & 78 \\
\hline Ресурси взаємин & 89 & 97 & 67 & 77 & 15 & 90 \\
\hline
\end{tabular}

Дискримінантна модель системної рефлексії містила такі компоненти ресурсної насиченості, як психологічна ресурсність, психологічне благополуччя, когерентність, сили характеру, персональна ресурсність, ресурси взаємин (коректність класифікування 57\% за значення Wilks' Lambda 0,91). Дискримінантна модель системної рефлексії не містила таких ресурсів, як екзистенційні ресурси, ресурси психологічного виживання, толерантність до невизначеності. Дискримінантна модель мудрості містила усі передбачувані стратегії (коректність класифікування 78\% за значення Wilks' Lambda 0,90 ) й усі компоненти ресурсної насиченості (коректність класифікування 83\% за значення Wilks' Lambda 0,63). (C) Shtepa Olena 
ISSN 2227-6246 (Print)

ISSN 2663-6956 (Online)

ПРОБЛЕМИ СУЧАСНОЇ ПСИХОЛОГІЇ

DOI: https://doi.org/10.32626/2227-6246.2020-48

2020. ВИПУСК 48

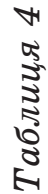

:

ชุน

危

일

:-1

ठ

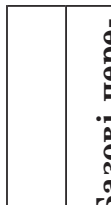

造

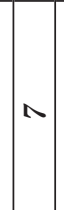

(1)

密

잉

百

党

.

要

㱐

穴

空

(1)

¿ :-10

$\rtimes$ 嵌

函

คै ญ

胫

$\checkmark$ 耐

百

कి

8

\%

$\sum_{i}$

幽

U

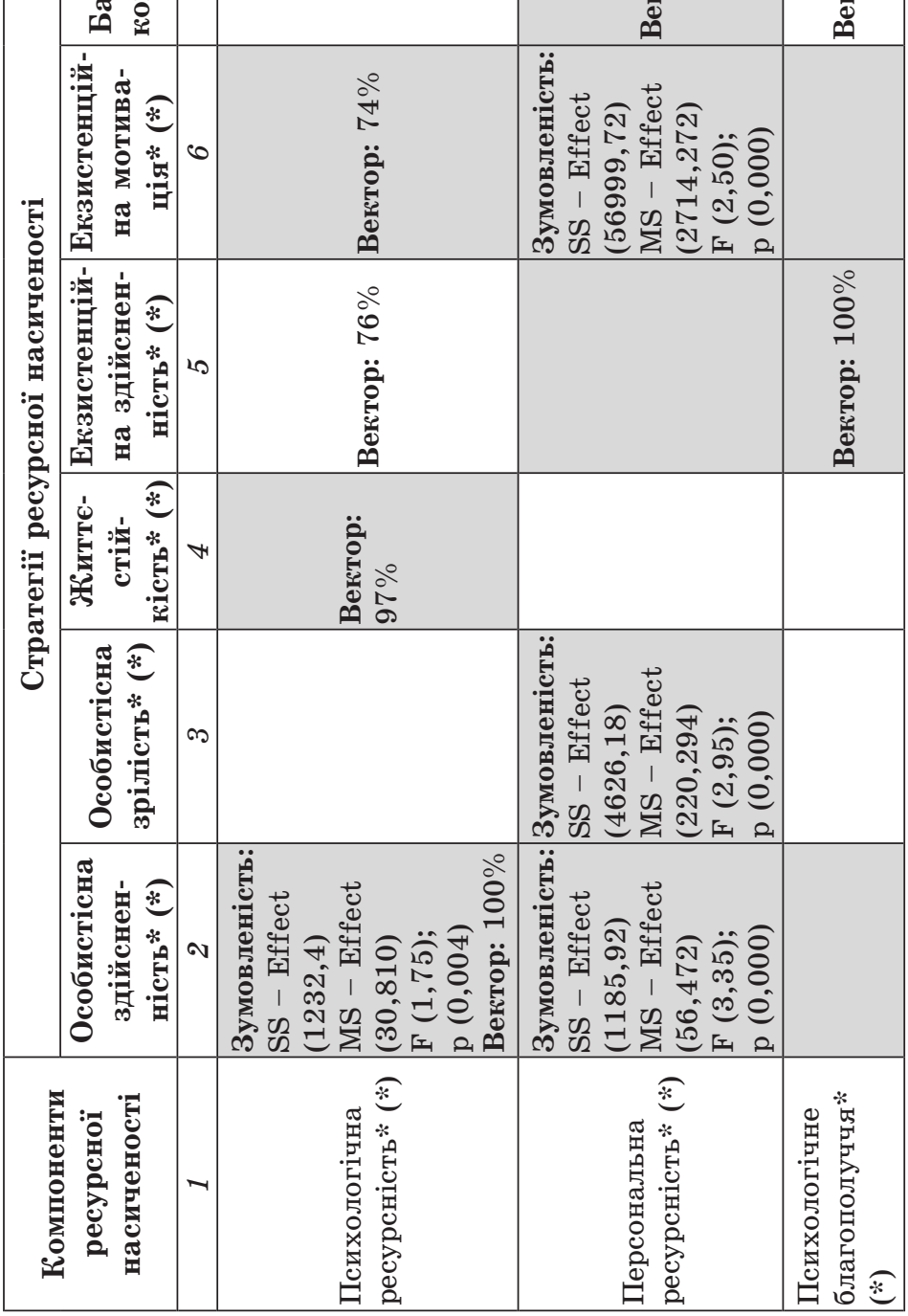

(C) Shtepa Olena

DOI (article): https://doi.org/10.32626/2227-6246.2020-48.313-338 
ISSN 2227-6246 (Print)

ISSN 2663-6956 (Online)

ПРОБЛЕМИ СУЧАСНОЇ ПСИХОЛОГІЇ

DOI: https://doi.org/10.32626/2227-6246.2020-48

2020. ВИПУСК 48

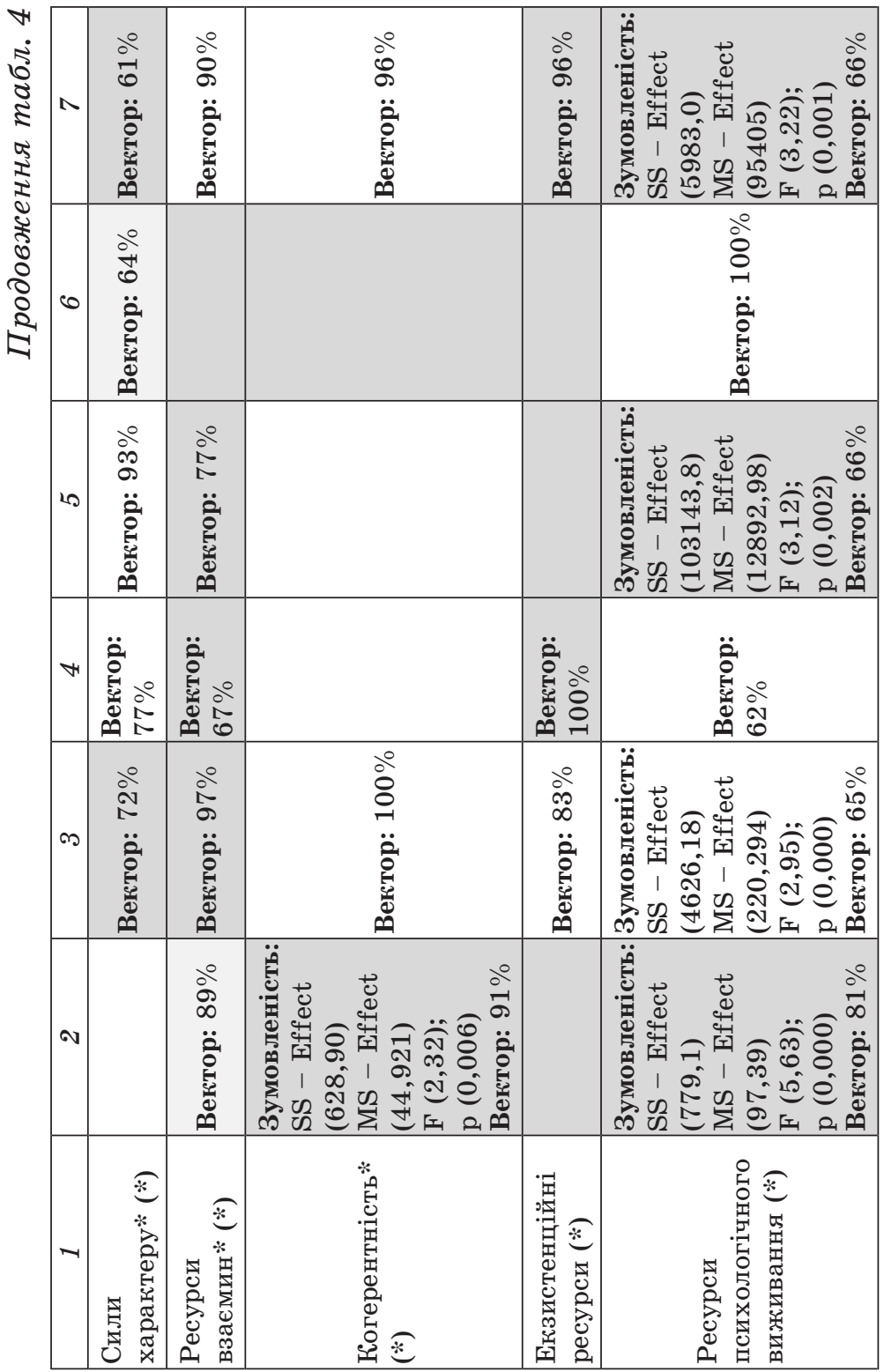

(C) Shtepa Olena

DOI (article): https://doi.org/10.32626/2227-6246.2020-48.313-338 
ISSN 2227-6246 (Print)

ISSN 2663-6956 (Online)

ПРОБЛЕМИ СУЧАСНОї ПСИХОЛОГІЇ

DOI: https://doi.org/10.32626/2227-6246.2020-48

2020. ВИПУСК 48
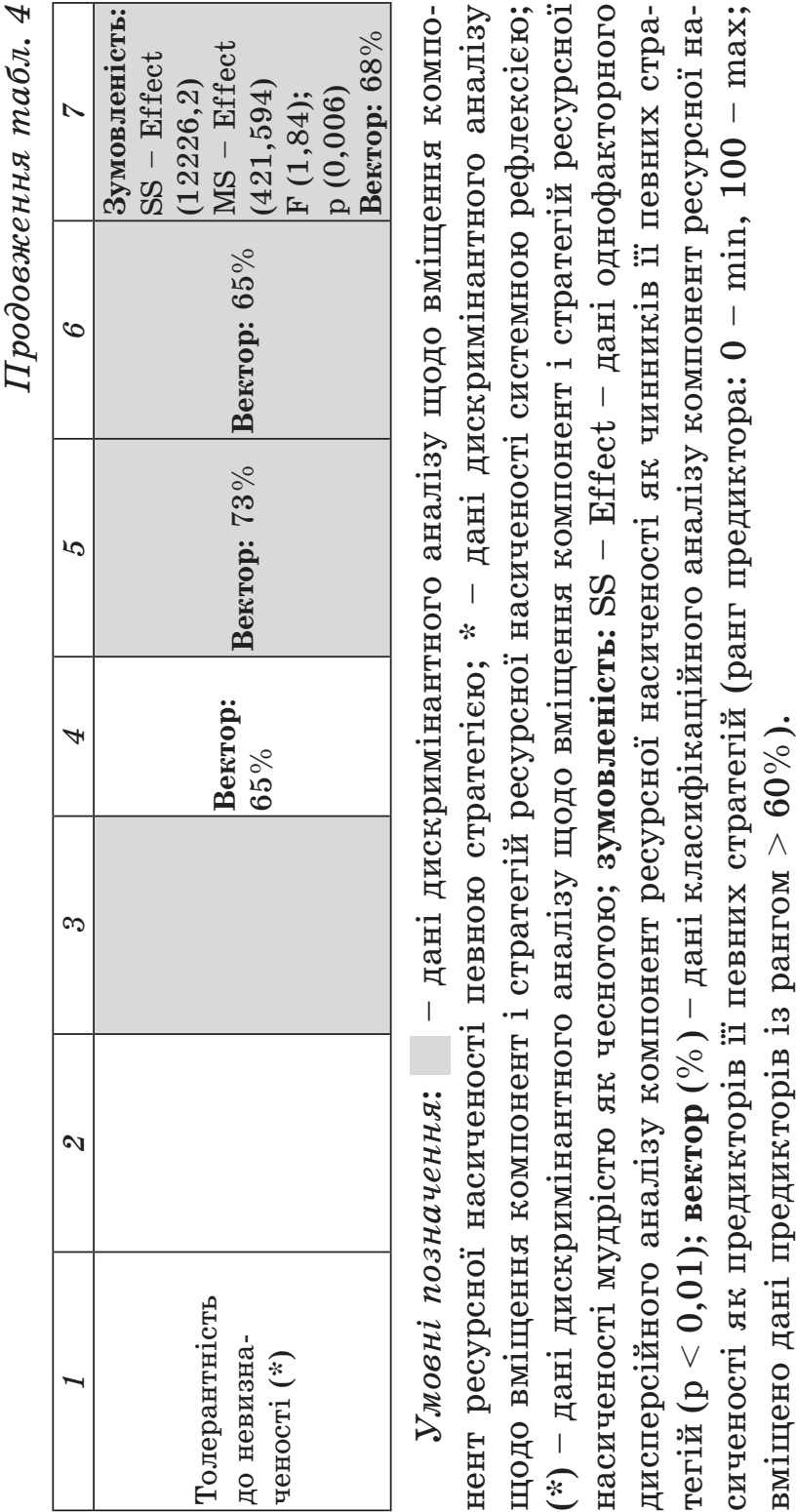

(C) Shtepa Olena

DOI (article): https://doi.org/10.32626/2227-6246.2020-48.313-338 
DOI: https://doi.org/10.32626/2227-6246.2020-48

2020. випУск 48

Узагальнені результати верифікації стратегій ресурсної насиченості за встановленими показниками вміщено у табл. 4.

Відповідно до еталонного визначення стратегії за В. Квинт (2016: 16), емпіричними критеріями характеристики стратегії ресурсної насиченості було визначено такі: мудрість - за даними дискримінантного аналізу щодо вміщення компонент і стратегій ресурсної насиченості мудрістю як чеснотою; вектор - за даними класифікаційного аналізу компонент ресурсної насиченості як предикторів їі певних стратегій; оцінка ресурсної обмеженості - за даними дискримінантного аналізу щодо вміщення компонент ресурсної насиченості певною стратегією, а також даними однофакторного дисперсійного аналізу компонент ресурсної насиченості як чинників ї̈ певних стратегій. На основі емпіричних даних можна стверджувати, що повною мірою цим критеріям стратегії відповідають такі динамічні властивості особистості, як особистісна здійсненність, особистісна зрілість, екзистенційна здійсненність, екзистенційна мотивація, базові переконання. Для зарахування життєстійкості до стратегій саме ресурсної насиченості немає підстав за критерієм ресурсної обмеженості, оскільки у нашому дослідженні не було виявлено, що певні психологічні ресурси зумовлюють зміни рівня життєстійкості.

Із метою характеристики сумірності стратегій ресурсної насиченості було застосовано кореляційний аналіз (табл. 5).

Результати кореляційного аналізу показали, що найменш тісними є зв'язки стратегії базових переконань 3 іншими стратегіями ресурсної насиченості особистості.

За допомогою класифікаційного аналізу (метод Predictor Variable Rankings) було встановлено, якою мірою певні стратегії ресурсної насиченості є предикторами можливості життєвого самоздійснення особистості (табл. 6). 
Інтеркореляції стратегій ресурсної насиченості

\begin{tabular}{|c|c|c|c|c|c|}
\hline $\begin{array}{c}\text { Стратегії } \\
\text { ресурсної } \\
\text { насиченості }\end{array}$ & $\begin{array}{c}\text { Особи- } \\
\text { стісна } \\
\text { здійснен- } \\
\text { ність } \\
\end{array}$ & $\begin{array}{l}\text { Особис- } \\
\text { тісна } \\
\text { зрілість }\end{array}$ & \begin{tabular}{|c|} 
Екзистен- \\
ційна \\
здійснен- \\
ність \\
\end{tabular} & $\begin{array}{c}\text { Екзистен- } \\
\text { ційна мо- } \\
\text { тивація }\end{array}$ & $\begin{array}{c}\text { Базові } \\
\text { переко- } \\
\text { нання }\end{array}$ \\
\hline $\begin{array}{l}\text { Особистісна } \\
\text { здійсненність } \\
\end{array}$ & 1,00 & & & & \\
\hline $\begin{array}{l}\text { Особистісна } \\
\text { зрілість }\end{array}$ & $0,53 * * *$ & 1,00 & & & \\
\hline $\begin{array}{l}\text { Екзистенційна } \\
\text { здійсненність }\end{array}$ & $0,47 * * *$ & $0,32 * * *$ & 1,00 & & \\
\hline \begin{tabular}{|l|} 
Екзистенційна \\
мотивація
\end{tabular} & $0,50 * * *$ & $0,61 * * *$ & $0,10 \%$ & 1,00 & \\
\hline $\begin{array}{l}\text { Базові } \\
\text { переконання }\end{array}$ & $0,10 *$ & $0,10 *$ & $0,14 * *$ & $0,12 *$ & 1,00 \\
\hline
\end{tabular}

Примітка: * p $<0,05 ; * * \mathrm{p}<0,01 ; * * * \mathrm{p}<0,001$.

Таблищя 6

Результати класифікаційного аналізу стратегій ресурсної насиченості як предикторів можливого життєвого самоздійснення особистості

\begin{tabular}{|l|c|}
\hline \multicolumn{1}{|c|}{ Стратегії ресурсної насиченості } & Ранг предиктора* \\
\hline Особистісна здійсненність & 100 \\
\hline Особистісна зрілість & 37 \\
\hline Екзистенційна здійсненність & 23 \\
\hline Екзистенційна мотивація & 9 \\
\hline Базові переконання & 26 \\
\hline
\end{tabular}

Примітка: *ранг предиктора: 0 - min, 100 - max.

Результати класифікаційного аналізу звертають значну увагу на те, що найвагоміше визначає можливість життєвого самоздійснення особистості саме стратегія особистісної (c) Shtepa Olena

DOI (article): https://doi.org/10.32626/2227-6246.2020-48.313-338 
DOI: https://doi.org/10.32626/2227-6246.2020-48 2020. ВипУСК 48 здійсненності (ранг 100\%). Водночас аналіз співвідношення представленості стратегій ресурсної насиченості у кількісно фіксованій можливості життєвого самоздійснення особистості вказує на те, що стратегія особистісної здійсненності реалізується в емпіричній особистості лише на 5\% (рис. 1).

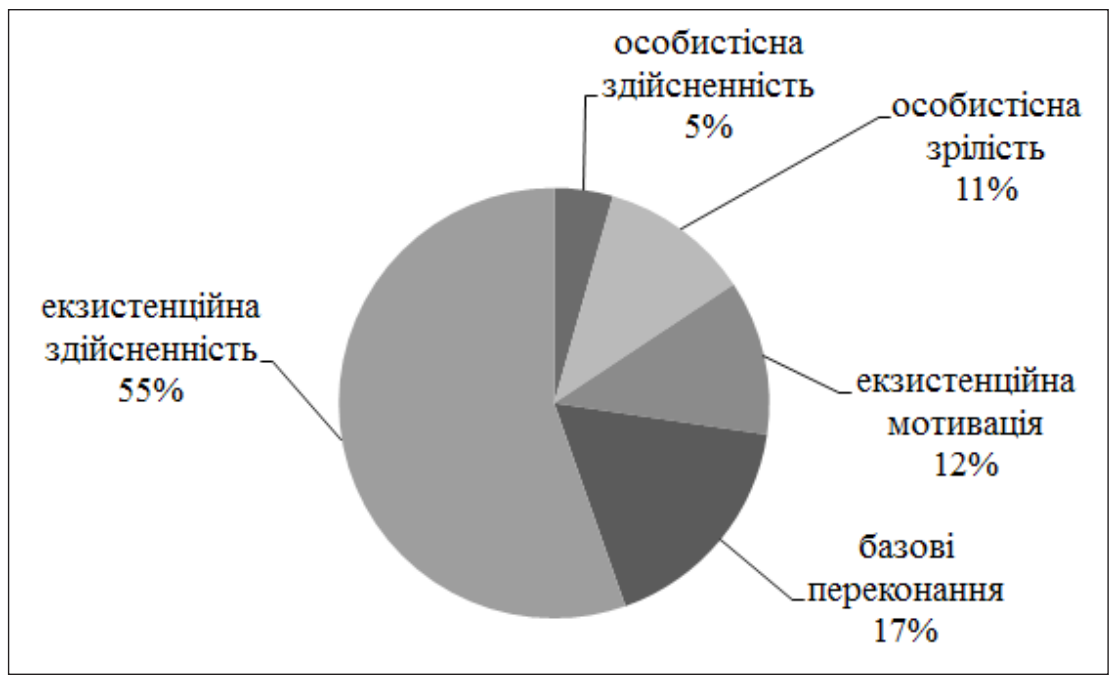

Puc. 1. Співвідношення стратегій ресурсної насиченості щодо можливості життєвого самоздійснення особистості

Понад половину (55\%) можливості життєвого самоздійснення скеровується стратегією екзистенційної здійсненності (iï ранг як предиктора складає 23\%). Вважаємо, що виявлене співвідношення значущості певних стратегій ресурсної здійсненності та їх кількісної вагомості для можливості життєвого самоздійснення особистості свідчить про різні функції стратегій.

Із метою встановити наявність кількісних показників зміни співвідношення стратегій ресурсної насиченості було застосовано однофакторний дисперсійний аналіз, за результатами якого встановлено, що кожна зі стратегій ресурс(C) Shtepa Olena

DOI (article): https://doi.org/10.32626/2227-6246.2020-48.313-338 
DOI: https://doi.org/10.32626/2227-6246.2020-48 2020. ВипУСК 48

ної насиченості зумовлює зміни рівня усіх інших стратегій. Водночас результати кластерного аналізу методом $k$-середніх показали, що можна охарактеризувати два типи можливості життєвого самоздійснення особистості, які різняться за показником стратегії екзистенційної здійсненності (рис. 2).

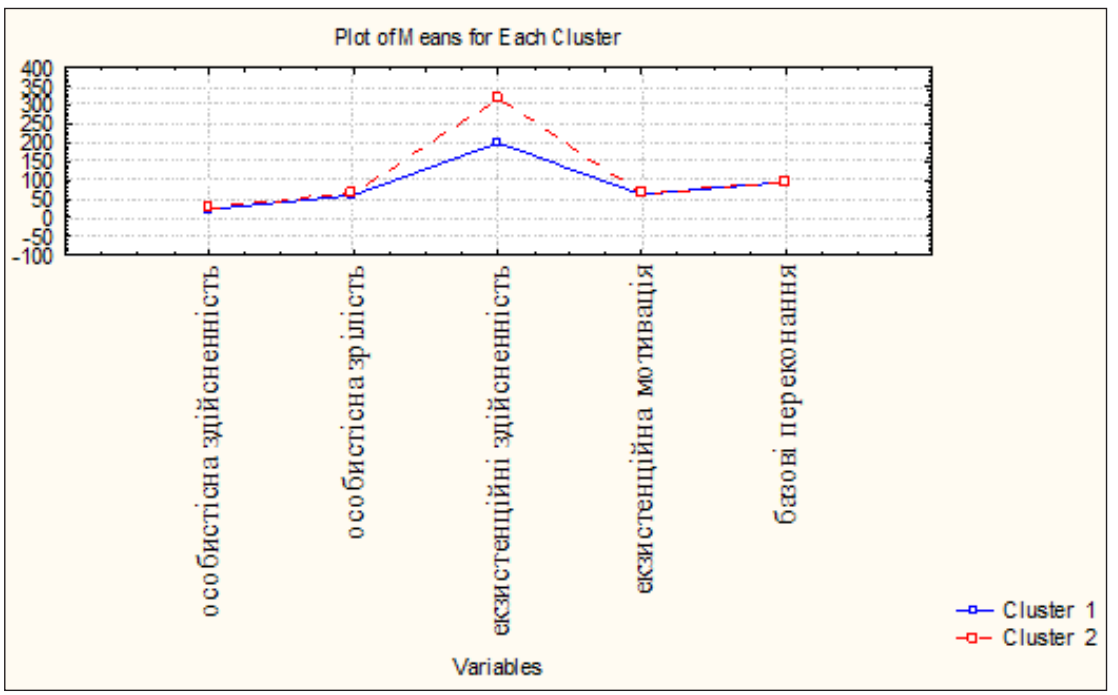

Уловні позначення: cluster 1 - знижений рівень екзистенційної здійсненності; cluster 2 - завищений тип екзистенційної здійсненності.

Puc. 2. Можливості життєвого самоздійснення особистості за показником стратегії екзистенційної здійсненності

Дані кількісних показників зміни співвідношення стратегій ресурсної насиченості дають підстави вважати, що екзистенційна здійсненність є атрактором можливості життєвого самоздійснення особистості.

На основі виведених критеріїв стратегії та результатів емпіричної верифікації напрямів стратегування ресурсної насиченості особистості можна стверджувати, що особистісна здійсненність, особистісна зрілість, екзистенційна здійс-

(C) Shtepa Olena

DOI (article): https://doi.org/10.32626/2227-6246.2020-48.313-338 
ненність, екзистенційна мотивація, базові переконання $€$ рефлексованими стратегіями ресурсної насиченості особистості, реалізація яких створює можливості життєвого самоздійснення. Оскільки рефлексія є умовою свідомого скерування особою психологічних ресурсів за певними напрямами можливості життєвого самоздійснення, то доцільніше схарактеризувати можливість життєвого самоздійснення не стільки, як власне динамічний стан, скільки «образ психічного стану» (Прохоров \& Артищева, 2012: 63), який характеризується злиттям знання, переживання і ставлення людини до події, а механізмами його виникнення і закріплення є внутрішні враження та зіставлення зі змістом минулого досвіду (Прохоров \& Артищева, 2012: 64). Допускаємо, що у структурі можливості життєвого самоздійснення стратегія особистісної зрілості характеризує ставлення, стратегія екзистенційної мотивації - переживання, стратегія базових переконань - знання особистості щодо можливості самоздійснення. На основі емпіричних даних вважаємо, що стратегії екзистенційної здійсненності й особистісної здійсненності $€$ механізмами утворення образу психічного стану уможливлювання самоздійснення. Зокрема, стратегія екзистенційної здійсненності, що передбачає відкритість новому досвіду, є механізмом представлення враження у внутрішній картині світу людини, а стратегія особистісної здійсненності - механізмом зіставлення наявного і нового досвіду особистості. Указане, на наш погляд, підтверджує, що стратегування ресурсної насиченості особистості відбувається відносно їі інтенційності.

\section{Висновки}

Із перспективною метою характеристики ефективності функціонування особистості в емпіричний спосіб було здійснено виокремлення стратегій ресурсної насиченості особистості. Локусом стратегування визначено інтенційність особистості, тому стратегування ресурсної насиченості сха(c) Shtepa Olena

DOI (article): https://doi.org/10.32626/2227-6246.2020-48.313-338 
рактеризовано як рефлексивно зумовлений розподіл психологічних ресурсів за напрямами інтенційного досвіду, що охоплюється мудрістю людини. Емпіричними показниками стратегування ресурсної насиченості визначено системну рефлексію, мудрість, психологічні ресурси особистості. Емпіричне обірунтування спрямування компонент ресурсної насиченості за певними їі стратегіями здійснено за допомогою однофакторного дисперсійного аналізу, дискримінантного i класифікаційного аналізу. Передбачалося, що такі динамічні особистісні властивості людини, як особистісна здійсненність, особистісна зрілість, екзистенційна здійсненність, екзистенційна мотивація, базові переконання, життєстійкість, є стратегіями ресурсної насиченості. Кожна із зазначених динамічних властивостей відносно одна одної були альтернативними гіпотезами, адже лише за результатами аналізу за висунутими емпіричними показниками стратегування було встановлено, чи є окреслені властивості стратегіями ресурсної насиченості. За результатами верифікації виокремлено такі стратегії ресурсної насиченості, як: особистісна здійсненність, особистісна зрілість, екзистенційна здійсненність, екзистенційна мотивація, базові переконання. Показано, що життєстійкість сумнівно допускати стратегією саме ресурсної насиченості особистості. Проінтерпретовано, що кожна з визначених стратегій характеризує певні функції в рефлексивно створюваному людиною образі власного можливого життєвого самоздійснення. Оскільки не стратегії утворюють ресурсну насиченість, а психологічні ресурси спрямовуються за стратегіями, то доцільно вказати, що ціллю устремління ресурсів є можливість життєвого самоздійснення. Відтак, стратегування психологічних ресурсів, на наш погляд, є не потребою особи, а виявом їі суб'єктної активності. Вважаємо, що подальша характеристика функцій психологічних ресурсів буде актуальною для прогнозування й аналізу ефективності функціонування особистості.

(C) Shtepa Olena

DOI (article): https://doi.org/10.32626/2227-6246.2020-48.313-338 


\section{Література}

Иванова Т., Леонтьев Д., Осин Е., Рассказова Е., Кошелева Н. Современные проблемы изучения личностных ресурсов в профессиональной деятельности. Организационная психология. 2018. Т. 8, № 1. C. 85-121. URL : https://www.orgpsyjournal.hse.ru.

Капустин С. А. Вклад У. Джемса в представления о личности как психологической реальности. Национальный психологический журнал. 2017. № 1 (25). С. 62-69. DOI 10.11621/npj.2017.01.08.

Квинт В. Л. Поиск и исследование философских корней теории стратегии. Взаимосвязь философского и стратегического мышления. Управленческое консультирование. 2016. № 1. С. 15-21.

Леонтьев Д. А. Перспективы неклассической психодиагностики. Психологические исследования: электронный научный журнал. 2010. № 4 (12). URL : http://psystudy.ru.0421000116/0031.

Леонтьев Д. А. Развитие личности в норме и в затрудненных условиях. Культурно-историческая психология. 2014. Т. 10, № 3. С. 97-106.

Леонтьев Д. А. Саморегуляция, ресурсы и личностный потенциал. $\mathrm{Cu}$ бирский психологический журнал. 2016. № 62. С. 18-37.

Низовских Н. А. Человек как автор самого себя: психосемантическое исследование личностного развития: монография. Москва - Берлин : Директ-Медиа, 2014. 405 с.

Прохоров А. О., Артищева Л. В. Образ психического состояния: динамические и структурные характеристики. Эксперилентальная психология. 2012. Т. 5, № 2. С. 63-73.

Пушкарев Ю. И. Личность как субъект адаптации и субъект интерпретации: системно-герменевтический подход к изучению личности: монография. Белгород : ИД «Белгород», 2012. 209 с.

Рязанцева О. Ю. Экзистенциальные ресурсы лиц, переживающих психологический кризис: дис. ... канд. психол. наук: 19.00.01. Одесca : Ужноукраинский национальный педагогический университет имени К. Д. Ушинского, 2012. 343 с.

Савчин М. Здатності особистості: монографія. Київ : ВЦ «Академія», 2016. 288 c.

Титов И. Г. Принципы постнеклассической психологии. Теоретичні дослідження у психологї̈: монографічна серія / укл. В. О. Мєдінцев. 2019. T. VII. C. 150-176. DOI 10.24411/2616-6860-2019-00005.

Хазова С. А. Ментальные ресурсы субъекта: природа, функции, динамика. Педагогика. Психология. Социальная работа. Ювенология. Социокинетика. Вестник КГУ ил. Н. А. Некрасова. 2014. Т. 20, № 41. C. 47-53.

Черникова И. В. Постнеклассическая наука и философия процесса. Томск : Изд-во НТЛ, 2007. 252 с.

(C) Shtepa Olena

DOI (article): https://doi.org/10.32626/2227-6246.2020-48.313-338 
Штепа О. С. Ресурсна насиченість особистості. Проблели сучасної психології: зб. наук. праць Кам'янець-Подільського національного університету ілені Івана Огієнка, Інституту психології ілені Г. С. Костюка НАПН України / за наук. ред. С. Д. Максилен$\kappa a$, Л. А. Онуфрієвої. Кам'янець-Подільський : ТОВ «Друкарня «Рута», 2020. Вип. 47. С. 231-252. URL : doi.org/10.32626/22276246.2020-47.231-252.

Як будувати власне майбутнє: життєві завдання особистості: наук. монографія / за наук. ред. Т. М. Титаренко; Національна академія педагогічних наук України, Інститут соціальної та політичної психології. Кіровоград : Імекс-ЛТД, 2012. 512 с.

Collis, David J., \& Rukstad, Michael J. (2008). Can you say what your strategy is? Harvard Business Review. April. (Reprint R0804E), (pp. 1-10). URL : www.hbr.org.

May, R. (1969). Love and Will. New York : W. W. Norton \& Co. 352 p. URL : http://goodreads.com.

\section{References}

Ivanova, T., Leontiev, D., Osin, E., Rasskazova, E., \& Kosheleva, N. (2018). Sovremennyie problemy izucheniia lichnostnykh resursov v professionalnoi deiatelnosti [Modern problems of the study of personality's resources in professional activities]. Organizatsionnaia psikhologiia - Organizational psychology, 8 (1), 85-121. Retrieved from https://www.orgpsyjournal.hse.ru [in Russian].

Kapustin, S. A. (2017). Vklad W. James v predstavleniia o lichnosti kak psikhologicheskoi realnosti [W. James's contribution to the concept of personality as a psychological reality]. Natsionalnyi psikhologicheskii zhurnal - National psychological journal, 1 (25), 62-69. DOI 10.11621/npj.2017.01.08 [in Russian].

Kvint, V. L. (2016). Poisk i issledovanie filosofskikh kornei teorii strategii. Vzaimosviaz filosofskogo i strategicheskogo myshleniia [Search and study of the philosophical origin of strategy theory. The relationship of philosophical and strategic thinking]. Upravlencheskoie konsultirovaniie - Management Consulting, 1, 15-21 [in Russian].

Leontiev, D. A. (2010). Perspektivy neklassicheskoi psikhodiagnostiki [Prospects for non-classical psychodiagnostics]. Psikhologicheskiie issledovaniia - Psychological research. Retrieved from http:// psystudy.ru.0421000116/0031 [in Russian].

Leontiev, D. A. (2014). Razvitiie lichnosti v norme i v zatrudnennykh usloviiakh. [Personality development under normal and difficult conditions]. Kulturno-istoricheskaia psikhologiia - Cultural and historical psychology, 10 (3), 97-106 [in Russian].

(C) Shtepa Olena

DOI (article): https://doi.org/10.32626/2227-6246.2020-48.313-338 
DOI: https://doi.org/10.32626/2227-6246.2020-48

2020. випУСК 48

Leontiev, D. A. (2016). Samoreguliatsiia, resursy i lichnostnyi potentsial [Self-regulation, resources and personal potential]. Sibirskii psikhologicheskii zhurnal - Siberian Psychological Journal, 62, 18-37 [in Russian].

Nizovskikh, N. A. (2014). Chelovek kak avtor samogo sebia: psikhosemanticheskoie issledovaniie lichnostnogo razvitiia [Man as an author of himself: a psychosemantic study of personal development]. Moskva Berlin : Direkt-Media [in Russian].

Prokhorov, A. O., \& Artishcheva, L. V. (2012). Obraz psikhicheskogo sostoianiia: dinamicheskiie i strukturnyie kharakteristiki [The image of a mental state: dynamic and structural characteristics]. Eksperimentalnaia psikhologiia - Experimental Psychology, 5 (2), 63-73 [in Russian].

Pushkarev, Yu. I. (2012). Lichnost kak subiekt adaptatsii i subiekt interpretatsii: sistemno-germenevticheskii podkhod $k$ izucheniiu lichnosti [Personality as a subject of adaptation and a subject of interpretation: a system-hermeneutic approach to the study of personality]. Belgorod : ID «Belgorod» [in Russian].

Riazantseva, E. Yu. (2012). Ekzistentsialnyie resursy lits, perezhivaiushchikh psikhologicheskii krizis [Existential resources of people having been in a psychological crisis]. Candidate's thesis. Odessa : Yuzhnoukrainskii natsionalnyi pedagogicheskii universitet imeni K. D. Ushinskogo [in Russian].

Savchyn, M. (2016). Zdatnosti osobystosti [Abilities of personality]. Kyiv : VTs «Akademiia» [in Ukrainian].

Titov, I. G. (2019). Printsipy postneklassicheskoi psikhologii [Principles of post-non-classical psychology]. V. O. Miedintsev (Ed.). Teoretychni doslidzhennia u psykholohii - Theoretical researches in psychology, VII, 150-176. DOI 10.24411/2616-6860-2019-00005 [in Russian].

Khazova, S. A. (2014). Mentalnyie resursy subiekta: priroda, funktsii, dinamika. [Mental resources of the subject: nature, functions, dynamics]. Pedagogika. Psikhologiia. Sotsialnaia rabota. Yuvenologiia. Sotsiokinetika. Vestnik KGU im. N. A. Nekrasova-Pedagogy. Psychology. Social work. Juvenology. Sociokinetics. Bulletin of KSU named after N. A. Nekrasov, 20, 47-53 [in Russian].

Chernikova, I. B. (2007). Postneklassicheskaia nauka i filosofiia protsessa [Post-non-classical science and philosophy of process]. Tomsk : Izd-vo NTL [in Russian].

Shtepa, O. S. (2020). Resursna nasychenist osobystosti [Resource's richness of personality]. Problemy suchasnoi psykholohii - Problems of Modern Psychology: Collection of research papers of Kamianets-Po-

(C) Shtepa Olena

DOI (article): https://doi.org/10.32626/2227-6246.2020-48.313-338 http://journals.uran.ua/index.php/2227-6246 
dilskyi National Ivan Ohiienko University, G. S. Kostiuk Institute of Psychology of the National Academy of Educational Sciences of Ukraine, 47, 231-252. Kamianets-Podilskyi : TOV «Drukarnia «Ruta». Retrieved from doi.org/10.32626/2227-6246.2020-47. 231-252 [in Ukrainian].

Tytarenko, T. M. (Ed.). (2012). Yak buduvaty vlasne maibutnie: zhyttievi zavdannia osobystosti [How to build your future: personal life goals]. National Academy of Educational Sciences of Ukraine, Institute of Social and Political Psychology. Kirovohrad : IMEKS-LTD [in Ukrainian].

Collis, David J., \& Rukstad, Michael J. (2008). Can you say what your strategy is? Harvard Business Review. April. (Reprint R0804E), 1-10. Retrieved from www.hbr.org.

May, R. (1969). Love and Will. New York : W. W. Norton \& Co. Retrieved from http://goodreads.com.

\section{Штепа Олена. Стратеаії ресурсної насиченості особистості}

\section{АНОТАЦІЯ}

Мета дослідження - емпірично визначити напрями стратегування ресурсної насиченості особистості.

Методи. Застосовано психологічне опитування з використанням таких методик, як: опитувальник персональної ресурсності, опитувальник психологічної ресурсності, тест-опитувальник діагностики показників екзистенційних ресурсів, опитувальник чеснот і сил характеру, опитувальник стратегій подолання кризового стану, опитувальник психологічного благополуччя, шкала когерентності, методика визначення інтолерантності до невизначеності, методика оцінки та прогнозування психологічного розвитку ситуацій міжособистісної взаємодії. Застосовано такі методи математико-статистичного аналізу, як однофакторний дисперсійний аналіз, кластерний аналіз, класирікаційний аналіз. Дослідження реалізовано за моделлю Голдмарка, що передбачає висунення альтернативних гіпотез і визначення практичної й теоретичної значущості результатів дослідження. Реалізовано метод верифікації й інтерпретації.

Результати дослідження. За результатами верифрікації виокремлено такі стратегії ресурсної насиченості, як: особистісна здійсненність, особистісна зрілість, екзистенційна здійсненність, екзистенційна мо-

(C) Shtepa Olena

DOI (article): https://doi.org/10.32626/2227-6246.2020-48.313-338 
DOI: https://doi.org/10.32626/2227-6246.2020-48 2020. ВиПУСК 48

тивація, базові переконання (коректність дискримінування становить 65,5\% за значення Wilks' Lambda 0,68). Показано, що життестійкість сумнівно допускати стратегією саме ресурсної насиченості особистості. За результатами класирікаційного аналізу встановлено, що найвагоміше визначає можливість життєвого самоздійснення особистості саме стратегія особистісної здійсненності (ранг предиктора 100\%). Аналіз співвідношення представленості стратегій ресурсної насиченості у структурі життєвого самоздійснення особистості вказує на те, що стратегія особистісної здійсненності має у ній частку лише 5\%, водночас стратегія екзистенційної здійсненності - 55\%, а їі ранг як предиктора складає 23\%. Результати кластерного аналізу методом k-середніх показали, що можна охарактеризувати два типи можливості життєвого самоздійснення особистості, які різняться за показником стратегії екзистенційної здійсненності.

Висновок. Стратегування ресурсної насиченості схарактеризовано як ресрлексивно зумовлений розподіл психологічних ресурсів за напрямами інтенційного досвіду, що охоплюється мудрістю людини. Емпіричними показниками стратегування ресурсної насиченості визначено системну рефлексію, мудрість, психологічні ресурси особистості. Проінтерпретовано, що кожна з визначених стратегій характеризує певні функції в рефллексивно створюваному людиною образі власного можливого життєвого самоздійснення. Характеристика функцій психологічних ресурсів є актуальною для прогнозування й аналізу ефективності функціонування особистості.

Ключові слова: стратегії ресурсної насиченості, психологічні ресурси, системна рефрлексія, можливості життєвого самоздійснення, мудрість, стратегування психологічних ресурсів.

\section{Штепа Елена. Стратегии ресурсной насыщенности личности}

\section{АННОТАЦИЯ}

Цель исследования - эмпирически определить направления стратегирования ресурсной насыщенности личности.

Методы. Применен психологический опрос с использованием опросника персональной ресурсности, опросника психологической ресурсности, тест-опросника диагностики показателей экзистенциальных ресурсов, опросника добродетелей и сил характера, опросника стратегий (c) Shtepa Olena

DOI (article): https://doi.org/10.32626/2227-6246.2020-48.313-338 http://journals.uran.ua/index.php/2227-6246 
преодоления кризисного состояния, опросника психологического благополучия, шкалы когерентности, методики определения толерантности к неопределенности, методики оценки и прогнозирования развития ситуаций межличностного взаимодействия. Применены такие методы математико-статистического анализа, как однофакторный дисперсионный анализ, кластерный и классификационный анализ. Исследование реализовано по модели Голдмарка, предполагающей выдвижение альтернативных гипотез и определение практической и теоретической значимости результатов исследования. Применены методы верификации и интерпретации.

Результаты исследования. На основе результатов верификации выделены такие стратегии ресурсной насыщенности: личностная исполненность, личностная зрелость, экзистенциальная исполненность, экзистенциальная мотивация, базовые убеждения (корректность дискриминирования составила 65,5\% при значении Wilks' Lambda 0,68). Cyществуют основания для сомнений в том, что жизнестойкость следует считать стратегией именно ресурсной насыщенности личности. На основе результатов классификационного анализа установлено, что наиболее значимо определяет возможность жизненного самоосуществления личности именно стратегия личностной исполненности (ранг предиктора 100\%). Анализ соотношения представленности стратегий ресурсной насыщенности в структуре жизненного самоосуществления личности указывает на то, что стратегия личностной исполненности составляет в ней лишь 5\%, в то время как стратегия экзистенциальной исполненности - 55\% (ее ранг как предиктора составляет 23\%). Результаты кластерного анализа методом k-средних показали, что можно характеризовать два типа возможности жизненного самоосуществления личности, которые различаются по показателю стратегии.

Вывод. Стратегирование ресурсной насыщенности личности охарактеризовано как рефрлексивно обусловленное распределение психологических ресурсов по направлениям интенционального опыта, охваченного мудростью человека. Эмпирическими показателями стратегирования ресурсной насыщенности личности определены системная рефллексия, мудрость, психологические ресурсы личности. Проинтерпретировано, что каждая из установленных стратегий характеризует определенные функиии в рефрлексивно создаваемом человеком образе его возможного жизненного самоосуществления. Характеристика функций психологиче-

(c) Shtepa Olena

DOI (article): https://doi.org/10.32626/2227-6246.2020-48.313-338 
ISSN 2227-6246 (Print)

DOI: https://doi.org/10.32626/2227-6246.2020-48 2020. ВиПУСК 48

ских ресурсов может быть актуальной для прогнозирования и анализа эффрективности функционирования личности.

Ключевые слова: стратегии ресурсной насыщенности, психологические ресурсы, системная рефлексия, возможности жизненного самоосуществления, мудрость, стратегирование психологических ресурсов.

Original manuscript received February 03, 2020

Revised manuscript accepted March 11, 2020

(C) Shtepa Olena

DOI (article): https://doi.org/10.32626/2227-6246.2020-48.313-338 http://journals.uran.ua/index.php/2227-6246 